\title{
EMPOWER YOUR RESEARCH WITH TRANSPORT! 30 YEARS TOGETHER
}

\author{
Olegas Prentkovskis ${ }^{1}$, Raimundas Junevičius ${ }^{2}$, Adolfas Baublys ${ }^{3}$ \\ ${ }^{1}$ Editor-in-Chief of the Research Journal TRANSPORT \\ ${ }^{2}$ Managing (Associate) Editor of the Research Journal TRANSPORT \\ ${ }^{3}$ Honorary Editor-in-Chief of the Research Journal TRANSPORT
}

1 October 2015

A timespan of 30 years can seem both lengthy and brief as perspective determines our perceptions. In terms of human years, this timespan would be considered a young age and, perhaps, not yet fully mature. Something similar could be said about a journal: it would be still on its path to maturity but could already be recognised on the international scene and perceived as a significant publication. For Research Journal TRANSPORT, this timespan of 30 years was critical as it was a journey that started with the journal's founding and continued with growth in the search for excellence. During this evolutionary process, many changes were made in relation to the status of the research journal, its publishing format, the editorial board, indexing and abstracting in scientific databases, etc.

This anniversary of the Research Journal TRANSPORT invites the academic community to consider the furthering of the popularity of the transport science nationally and internationally.

Transport is among the key economic areas of a country. The development of modern economics relies on the well-functioning transport sector. The operation of industries and various sectors, including construction, agriculture and services, depend on transport. Furthermore, it is indispensable to humans as means for exercising their freedoms and actualising their aspirations.

Demands of the society for high-quality and timely transportation are important for the transport sector as they indicate the customer perceptions of the quality of transport services as well as the functionality of the universe of processes that run within a country.

Growing volumes of transportation and increasing requirements for the quality of transport services necessitate the continuous improvement of transport operations and their efficiency.

The sustainable development of national economics requires an increased focus on transport organisation and management issues. In this respect, a number of improvements are imperative, including enhanced plan- ning accuracy. In addition, further investigations must be undertaken into the assessment of transport systems and single vehicles. Rational transportation options are only possible based on precise calculations and under the condition of the careful use of resources. A solution that meets customer demands and is economical guarantees a transport company with further development and stable profits.

Clearly, transportation is impossible without vehicles. Means of transportation is yet another important subject in the array of topics that are covered by the research journal. The structure and operating principles of vehicles are constantly excelled to facilitate a greater number of performed features, and research findings in this area are an important driver of this progress.

Yet another vital objective for the transport sector is an increase in transportation volumes under safe traffic conditions. Many elements of the transport infrastructure impact on the operation of vehicles and negative factors must be considered, such as poor condition of roads, inefficiently organised traffic, technical flaws of vehicles, poor weather conditions, visibility, increased traffic density, control of a vehicle at unsafe speed, etc.

Considering the role of the transport sector and the array of relevant issues and challenges, transport specialists and national authorities have to collectively focus on the sustainable operation of this sector. Certainly, fundamental and applied research in the area of transport plays a crucial role.

The Research Journal TRANSPORT has been published since 1986:

- in the period from 1986 to 1991, the journal was published under the title Proceedings of the Higher Schools in Lithuania: Автомобильный транспорт/ Automobiliu transportas (Automobile Transport). All publications were prepared in Russian and included summaries in Lithuanian and English. The annual periodicity of the Journal was one volume - one issue;

- in the period from 1992 to 1994, the journal was re-

Corresponding author: Olegas Prentkovskis

E-mail: olegas.prentkovskis@vgtu.lt 
leased under a new title Proceedings of Vilnius Technical University: Transportas/Transport Engineering. It was decided to publish papers in Lithuanian, English and Russian. The periodicity of the journal remained unchanged, i.e. one volume (one issue) per year;

- in the period from 1995 to 2002, the journal changed the title again and became the Research Journal of Vilnius Gediminas Technical University and the Lithuanian Academy of Sciences: Transportas/Transport Engineering/Tpaнcnopm. Papers were continued to be published in three languages; however, the periodicity of the journal changed into one volume - two issues per year from 1995 to 1997 and one volume - six issues per year from 1998 to 2001;

- in the period from 2002 to 2005 , the journal was renamed to TRANSPORT and manuscripts were accepted in English only. The annual periodicity of the journal remained one volume (six issues);

- since 2011, the Research Journal TRANSPORT is copublished by Vilnius Gediminas Technical University and Taylor \& Francis.

Over time, the title of the Journal changed but despite various periods and publishers the Research Journal TRANSPORT has remained a flagship among the journals of the Baltic Region and the world. The journal continues to offer scientific articles on transport engineering, transport management and transport economics aiming to find the best solutions that would make all traffic participants safe, processes fast and used technology smart and friendly to both customer and environment. Therefore, papers are welcome on the following fields of research: transport policy; fundamentals of the transport system; technology for carrying passengers and freight using roads, railway, inland waterways, sea and air transport; technology for multimodal transportation and logistics; loading technologies; roads, railways, airports, ports; pipeline transport; industrial and technological transport; agricultural motor vehicles; traffic safety and environment protection; motor vehicles: design, manufacture and exploitation; transport energetics; fuels, lubricants and maintenance materials; teamwork of customs and transport; insurance; transport information technologies; transport economics and management; transport standards; transport educology; transport history. Beside papers, the journal also publishes short reports and conference proceedings.

Since the beginning of the history of the journal, the status of the Editorial Board evolved from national to international. Currently, the Editorial Board has 43 members from 19 countries. 15 members carry out research in transport engineering and transport management fields and represent the largest Lithuanian universities and companies while 28 members are from research institutes or universities located in:

- Belgium (University of Mons);

- China (Shanghai Maritime University and Changan University);

- Croatia (University of Rijeka);

- Denmark (Technical University of Denmark);

- Estonia (Tallinn University of Technology and Tallinn University of Applied Sciences);

- Finland (University of Turku);
- Germany (Ilmenau University of Technology);

- Greece (Center for Research and Technology Hellas CERTH);

- Hungary (Budapest University of Technology and Economics);

- Italy (University of Calabria, University of Messina);

- Latvia (Riga Technical University, Transport and Telecommunication Institute);

- Lithuania (Vilnius Gediminas Technical University, Kaunas University of Technology, Klaipeda University and JSC Lietuvos geležinkeliai);

- Poland (Silesian University of Technology);

- Russian Federation (Ulyanovsk State Technical University);

- Serbia (University of Belgrade);

- Slovenia (University of Maribor);

- Ukraine (National Aviation University, National University of Transport and Ternopil Ivan Pul'uj National Technical University);

- United Kingdom (Edinburgh Napier University);

- United States (Iowa State University and Lighting Research Center of the Rensselaer Polytechnic Institute).

The Research Journal TRANSPORT is also available in the electronic format. It is abstracted and indexed in: - Thomson Reuters: Science Citation Index Expanded, Web of Science;

- Elsevier Bibliographic Databases: SCOPUS, Compendex, PaperChem, The Engineering Index Monthly;

- ICONDA (The International CONstruction DAtabase);

- CSA (Cambridge Scientific Abstracts): Advanced Polymers Abstracts, Aerospace \& High Technology Database, Aluminum Industry Abstracts, Biological Sciences, CSA Civil Engineering Abstracts, CSA Engineering Research Database, CSA High Technology Research Database with Aerospace, CSA Materials Research Database with METADEX, CSA Mechanical \& Transportation Engineering Abstracts, CSA Sustainability Science Abstracts, CSA Technology Research Database, Ceramic Abstracts / World Ceramic Abstracts, Composites Industry Abstracts, Computer and Information Systems Abstracts Journal, Corrosion Abstracts, Earthquake Engineering Abstracts, Electronics and Communications Abstracts Journal, Engineered Materials Abstracts, Environmental Engineering Abstracts, Environmental Sciences and Pollution Management, Health and Safety Science Abstracts, International Aerospace Abstracts, Materials Business File, METADEX, Pollution Abstracts, Solid State and Superconductivity Abstracts;

- TRID;

- Gale ${ }^{\oplus}$ Academic OneFile, InfoTrac Custom;

- VINITI RAN;

- ProQuest: Ulrich's, Summon ${ }^{\mathrm{mm}}$;

- EBSCOhost: Academic Search Complete, Current Abstracts, TOC Premier;

- IndexCopernicus.

Researchers from all countries are welcome to publish their scientific papers in the Research Journal TRANSPORT co-published by Vilnius Gediminas Technical University and Taylor \& Francis! 